INDEPENDENT JOURNAL OF MANAGEMENT \& PRODUCTION (IJM\&P)

http://www.ijmp.jor.br

v. 12, n. 5, July-August 2021

ISSN: 2236-269X

DOI: 10.14807/ijmp.v12i5.1425

\title{
RELATIONSHIP BETWEEN SOCIAL MEDIA MARKETING PRACTICES AND CUSTOMER RESPONSE WITH MEDIATING ROLE OF BRAND EQUITY DIMENSIONS: AN EMPIRICAL \\ INVESTIGATION
}

\author{
Elmira Shadiardehaei \\ Department of Management, Aliabad Katoul Branch, Islamic Azad \\ University, Aliabad Katoul, Iran \\ E-mail:elmira_shadi99@yahoo.com \\ Ailar Ebrahimi Hesari \\ Department of Management, Aliabad Katoul Branch, Islamic Azad \\ University, Aliabad Katoul, Iran \\ E-mail: ailar.ebrahimi@gmail.com \\ Behzad Shahrabi \\ Department of Management, Aliabad Katoul Branch, Islamic Azad \\ University, Aliabad Katoul, Iran \\ E-mail: b.shahrabi@gmail.com
}

Submission: 8/17/2020

Revision: $9 / 9 / 2020$

Accept: 9/29/2020

\section{ABSTRACT}

This study aims to investigate the relationship between social media marketing practices and customer response with consideration of the mediating role of brand equity dimensions through structural equation modeling in an empirical case study. Data are analyzed using structural equation modeling. The following findings are found: The results show that there is a significant relationship between social media marketing practices and customer response in the survey sample. Additionally, the hypothesis about the mediating role of brand equity dimensions is also supported. The results of our research augment our understanding of the role of social media marketing practices in stimulating customer response (electronic word-of-mouth and commitment) and the role of brand equity dimensions (brand awareness and brand image).

Keywords: Social Media; Customer Response; Brand Equity 
ISSN: $2236-269 X$

DOI: 10.14807/ijmp.v12i5.1425

\section{INTRODUCTION}

Identifying variables that affect customer behavior is very important for many organizations and companies because it provides an opportunity to reduce costs and consequently increase profits and affects many areas of performance in organizations. In a competitive age, research on customer behavioral responses is more important and the direct and indirect consequences of these decisions on organizations have become more serious because the number of these organizations is increasing and they need to identify the effective factors to attract more customers to buy their services.

The realm of consumer behavior is like a sea that everyone can know only a part of, consumer behavior is formed under the influence of internal and external factors; given that consumers operate in a dynamic and ever-changing environment, and that consumer products and services are constantly evolving, marketing managers need to have an accurate understanding of consumer behavior to recognize this constant flow and create an appropriate marketing mix for a defined market (Kotler et al., 2014).

Customers may express their needs and demands in one way but act differently. They may not be aware of their deeper inner motivations or react to influential factors that change their mind at the last moment. However, marketers need to consider the demands of their customers, their perceptions, and their behavior. Many studies have identified effective factors on customers' behavioral responses in terms of cognitive, attitudinal, and value variables. Despite the proliferation of this series of studies, questions about customer behavioral responses are still not fully answered (Olson et al., 2009).

On the other hand, social media is now becoming the most important channel for business and communication with customers. This adaptation of social media for business communication stems from the fact that the Internet user community is expanding rapidly (Nguyen et al., 2015). In business, the ability to obtain information from social media and disseminate information to a wider audience, and the ability to integrate different channels as part of marketing programs are critical to the development of successful branding strategies through social media (Kim \& Ko, 2012; Rapp et al., 2013; Hsu \& Lawrence, 2016). Therefore, the present study tends to examine the relationship between social media marketing practices and customer response with the mediating role of brand equity dimensions.

One of the most famous and perhaps the most important marketing concepts today, first formed in the 1980s, is the concept of brand equity. Aaker (1996) introduces the concept of 
INDEPENDENT JOURNAL OF MANAGEMENT \& PRODUCTION (IJM\&P)

http://www.ijmp.jor.br

v. 12, n. 5, July-August 2021

ISSN: 2236-269X

DOI: 10.14807/ijmp.v12i5.1425

brand equity as brand-related assets (or liabilities) associated with a brand that increases or decreases the value of a good/service and includes brand awareness, quality received, brand links, and other brand-related assets.

Brand equity is created when customers tend to pay more for the same level of brand quality because of the interesting brand name and strong attachment to it (Moliner-Velázquez et al., 2019). Brand equity has many advantages for companies and manufacturers; for example, if the brand has a high equity value, the target consumer will have a positive attitude towards the brand and as a result be willing to pay a high price for the product, repeat the purchase, and do word-of-mouth advertising for the product (Kim \& Hyun, 2011; Ansary \& Hashim, 2018; Moise et al., 2019).

Brand equity has a positive effect on customer perception and consequently customer buying behaviors. To increase the likelihood of such a positive partnership and manage brand assets, companies need to develop strategies that increase and grow brand equity.

On the other hand, rapid change in today's world has faced companies with various challenges, but in the meantime, those companies are successful that can take advantage of the opportunities created by using management tools and new technologies. Given the importance of social media and the Internet, which facilitates direct and unmediated relationships between companies and customers (Ahmed et al., 2019; Kumar et al., 2016), it is claimed that social media, especially social networks can support brands by creating and maintaining relationships between companies and customers in these types of environments.

With the increasing acceptance of the Internet by the general public in society, the importance of social media as one of the Internet marketing tools is increasing (Clark et al., 2017). Companies can use social media to sell their products and create a new direct distribution channel for customers to buy as they wish. The Internet has enabled even small companies to connect with customers around the world. Social media such as Facebook, Twitter, etc. are rapidly gaining popularity due to providing immediate interactions and experiences for users (Heggestuen \& Danova, 2013).

Despite the popularity and ubiquity of social media, their importance in shaping online business interactions, and customer behaviors, little research has been done on the effect of social media on customer behavior. Understanding consumer behavior and knowing customers is not an easy task. Customers may express their needs and demands in some way but act 
INDEPENDENT JOURNAL OF MANAGEMENT \& PRODUCTION (IJM\&P)

http://www.ijmp.jor.br

v. 12, n. 5, July-August 2021

ISSN: 2236-269X

DOI: 10.14807/ijmp.v12i5.1425

differently. They may not be aware of their deeper inner motivations or react to influential factors that change their mind at the last moment.

However, marketers need to consider the needs of their customers, their mental perceptions, and their buying behavior. Therefore, to identify the effective factors on customer response, the present study tends to examine the role of social media marketing on brand equity and consumer behavior. Thus, the main problem of the present study is whether social media marketing practices affect customer response through the mediating role of brand equity dimensions.

\section{LITERATURE REVIEW}

Seo and Park (2018) conducted a study on the effect of social media marketing practices on brand equity and the response of airline customers in Korea. The results showed that social media marketing practices had a positive and significant effect on brand image and brand awareness. Brand awareness had a positive and significant effect on commitment, but its effect was not significant on electronic word-of-mouth advertising. The effect of brand image was positive and significant on commitment and word of mouth electronic advertising.

Ramanathan et al. (2017) in a study examined the effect of social media, service operations, and brand satisfaction on customer satisfaction with an emphasis on the moderating role of promotions. The results showed that the effect of social media and service operations was positive and significant on customer satisfaction, while the effect of brand satisfaction was not significant. Promotions had a positive moderating effect on the effect of service operations on customer satisfaction, while its moderating role in the relationship between social media and customer satisfaction was not significant.

Godey et al. (2016) examined the effect of social media marketing efforts of luxury brands on brand equity and consumer behavior in France, China, India, and Italy. The results showed that social media marketing efforts had a positive and significant effect on brand equity and consumer behavior. Brand equity had a positive and significant effect on consumer behavior. Brand equity mediated the relationship between social media marketing efforts and consumer behavior.

Chen and Shen (2015) conducted a study on the decisions of Chinese customers in the context of social business. The results showed that informational and emotional support had a significant effect on customer trust and commitment, as well as social purchasing and social sharing intention. Hudson et al. (2015) in a study examined the effect of interactions on social 
DOI: 10.14807/ijmp.v12i5.1425

media on emotional communication, the quality of brand communication, and word of mouth of university students in the United States.

The results showed that social media interactions had a positive and significant effect on emotional communication but its effect was not significant on the quality of brand communication. Emotional communication had a positive and significant effect on the quality of brand communication and word of mouth. The effect of brand communication quality was significant on word of mouth.

Kim and Ko (2012), to see whether social media marketing promotes customers' net assets, conducted an experimental study on a luxury goods brand in Korea. The results of this study showed that five components of social media marketing, including entertainment, interactivity, customer informing, formability, and word-of-mouth advertising had positive significant effects on the net worth asset, relationship net asset, and brand net asset. Regarding the relationships between the motivating factors of the customer's net asset, the brand net asset had a negative and significant effect on the customer's net worth.

Kim et al. (2011) conducted a study on the intention to buy digital goods in social media communities; 225 Korean consumers on social media took part in the study. The research method was a descriptive survey. A structural equation model was used to analyze the data. Marketing through social media had a direct impact on brand equity and brand equity itself had a positive effect on customer purchase intentions.

Chang and Liu (2009) in a study examined the relationship between brand equity, brand preferences, and purchase intention among airport passengers. The research method was a descriptive survey. A structural equation model was used to analyze the data. The statistical population of the study was users of Chinese banking and Internet services, of which 456 participated in the study. The results showed a positive relationship between brand equity and brand preferences and purchase intention with the mediating effect of switching on the relationship between brand value and purchase intention.

\section{HYPOTHESIS}

To define the hypotheses, the variables are first defined.

- Social media marketing: Social media marketing refers to a company's use of social media to interact with customers and influence customer attitudes and 
DOI: 10.14807/ijmp.v12i5.1425

behaviors to attract new customers and retain existing customers (Godey et al., 2016).

- Brand equity: Brand equity is a set of assets and liabilities associated with a brand that increases or decreases the value provided by a product or service to a company or its customers (Aaker, 1996). In the present study, brand equity refers to brand image and brand awareness. The brand image refers to strong, desirable, and unique associations in memory that results in perceived quality, positive attitude, and an overall positive impact. Brand awareness is the ability to recognize and remind potential buyers about a brand as a member of a particular product category (Seo \& Park, 2018).

- Customer response: Customer response includes the mental, emotional, and physical activities that people use when selecting, purchasing, using and disposing of products and services that meet their needs and demands. In the present study, customer response refers to word-of-mouth electronic advertising and commitment. Electronic word-of-mouth advertising is defined as all informal consumer communication through Internet-based technology, concerning the use or characteristics of specific goods or services or their vendors (Litvin et al., 2008).

Figure 1 shows the conceptual model of the study according to Seo and Park (2018). According to this model, social media marketing practices (entertainment, interaction, trendiness, customization, and perceived risk) are independent variables; customer response (electronic word-of-mouth advertising and commitment) are dependent variables and brand equity (brand awareness and brand image) are mediating variables. According to this model, social media marketing practices affect brand awareness and brand image and thus affect customer responses (electronic word of mouth advertising and commitment).

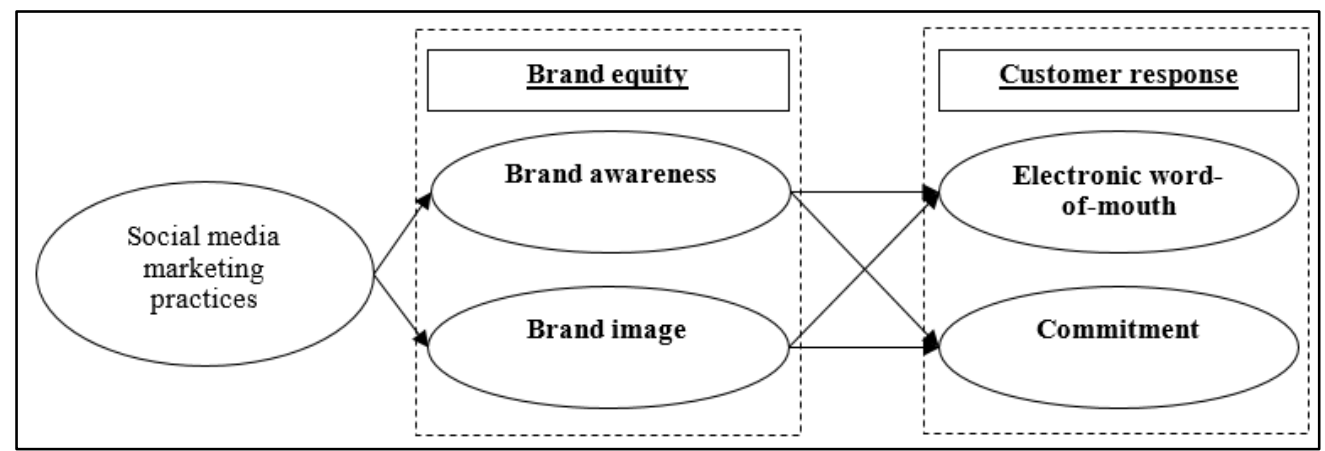

Figure 1: Conceptual model 
DOI: 10.14807/ijmp.v12i5.1425

- H1: There is a significant relationship between social medial marketing practices and brand awareness.

- H2: There is a significant relationship between social medial marketing practices and brand image.

- H3: There is a significant relationship between brand awareness and electronic word-of-mouth.

- H4: There is a significant relationship between brand image and electronic wordof-mouth.

- H5: There is a significant relationship between brand awareness and commitment.

- H6: There is a significant relationship between brand image and commitment.

\section{RESEARCH METHODOLOGY}

\subsection{Sample and Procedure}

Currently, Digikala website plays the leading role in online sales in Iran. Although many other similar websites operate in Iran, Digikala accounts for more than $85 \%$ of the country's retail market. This website, which started its activity about 12 years ago with only 5 employees, currently has more than 1000 employees in the fields of programming, sales, customer service, etc., and is expanding day by day and it is getting stronger; in a way that in different cities of Iran, it has 16 agencies to serve buyers and recently has developed two subcategories called Digistyle (exclusive online clothing store) and Fidibo (exclusively for buying and reading all kinds of books). The statistical population of the present study is customers of Digikala online store. In the present study, the statistical population is infinite; when the size of the statistical population is infinite, the number of samples using the Cochran's formula will be 384 people.

\subsection{Measurement Instruments}

- Social media marketing practices: the questionnaire developed by Seo and Park (2018) is used to measure social media marketing practices. The questionnaire has 11 items that measure entertainment (2 items), interaction (3 items), trendiness (2 items), customization ( 2 items), and perceived risk ( 2 items). The average score obtained from the items will represent social media marketing practices. Items were measured on a five-point Likert scale from strongly agree (1) to strongly agree (5). 
DOI: 10.14807/ijmp.v12i5.1425

- Brand equity: the questionnaire developed by Seo and Park (2018) is used to measure brand equity. The questionnaire has 6 items that measure brand awareness (3 items) and brand image (3 items). The average score obtained from the items will represent brand equity. Items were measured on a five-point Likert scale from strongly agree (1) to strongly agree (5).

- Customer response: the questionnaire developed by Seo and Park (2018) is used to measure customer response. The questionnaire has 6 items that measure electronic word-of-mouth (3 items) and commitment (3 items). The average score obtained from the items will represent customer response. Items were measured on a five-point Likert scale from strongly agree (1) to strongly agree (5).

\subsection{Confirmatory Factor Analysis}

\subsubsection{Second-order confirmatory factor analysis of social medial marketing practices}

In the present study, social media marketing practices have four components that can act as indicators of this construct. Therefore, the second-order factor analysis is investigated to test the measurement model as well as the validity of components of social media marketing practices (Figure 2).

The results of Figure 2 show that factor loads of the indicators (questions) related to each component and factor load of each component as an indicator of social media marketing practices are good in predicting this variable. The fit indexes of the measurement model for social media marketing practices show that the model has a very good fit.

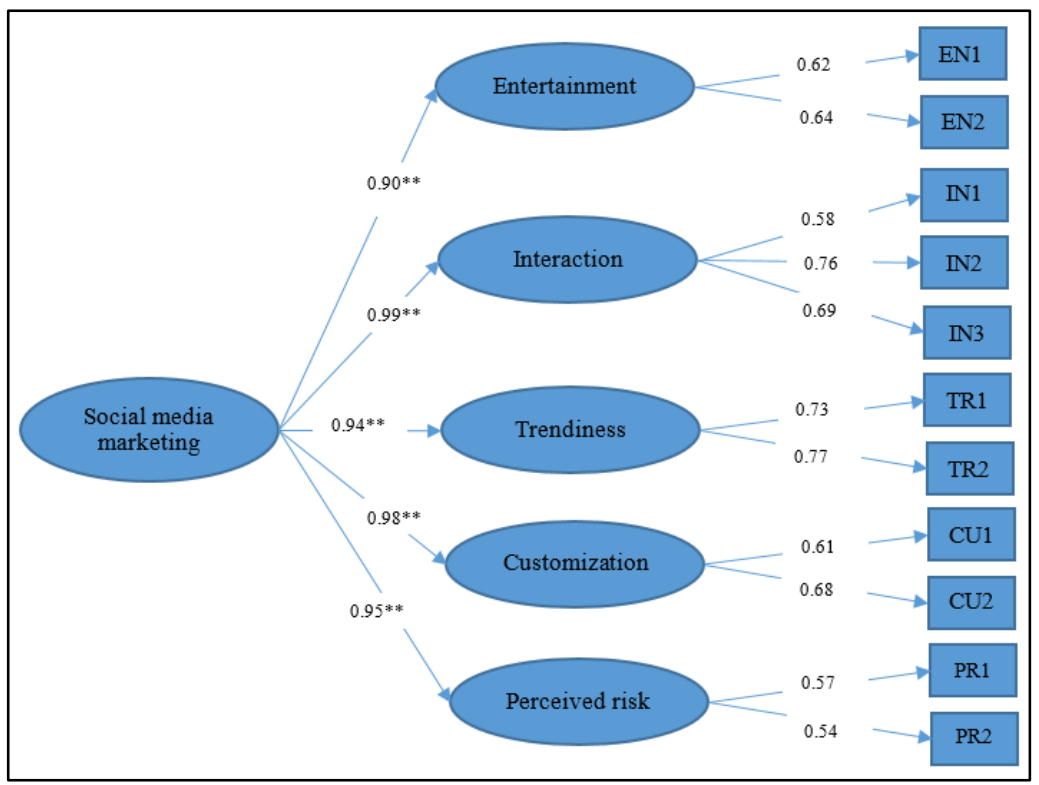

Figure 2: second-order confirmatory factor analysis for social medial marketing practices 
DOI: 10.14807/ijmp.v12i5.1425

\subsubsection{Confirmatory Factor Analysis of Brand Equity}

Confirmatory factor analysis was used to determine the validity of brand equity components. Figure 3 reports the factor loads of t-values. The numbers on paths are factor loads. All factor loads are higher than 0.3. Findings related to fit indices of brand equity components indicate that CFI, GFI, NFI, RMR, and RMSEA indices are at an acceptable level based on Noruzy et al. (2013) and Gholmai et al. (2013).

\subsubsection{Confirmatory Factor Analysis of Customer Responses}

Confirmatory factor analysis was used to determine the validity of customer responses. Figure 4 reports the factor loads of t-values. The numbers on paths are factor loads. All factor loads are higher than 0.3. Findings related to fit indices of customer responses indicate that CFI, GFI, NFI, RMR, and RMSEA indices are at an acceptable level. These goodness of fit indices show that data of this study have a good fit with the factor structure of this scale.

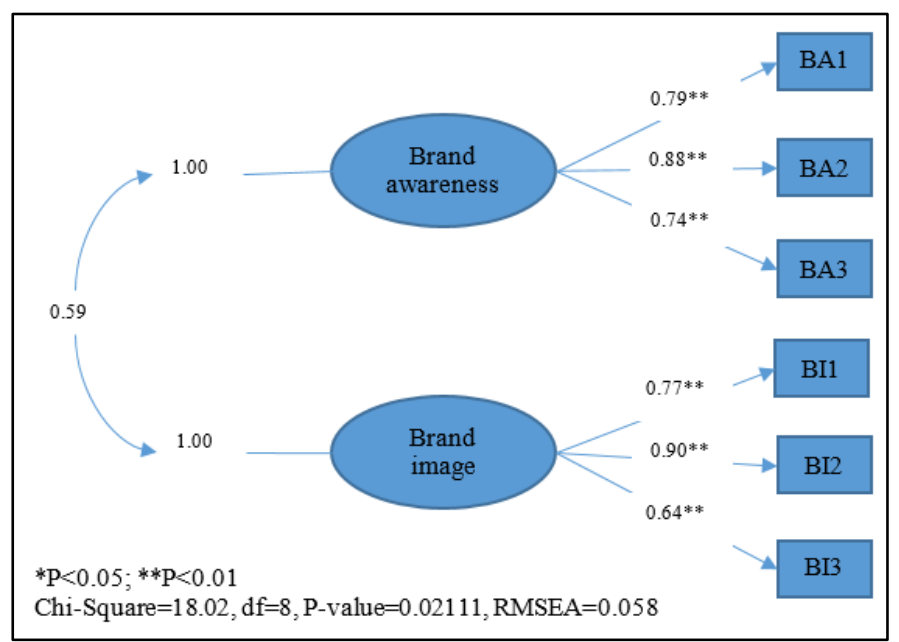

Figure 1: LISREL output for brand equity components

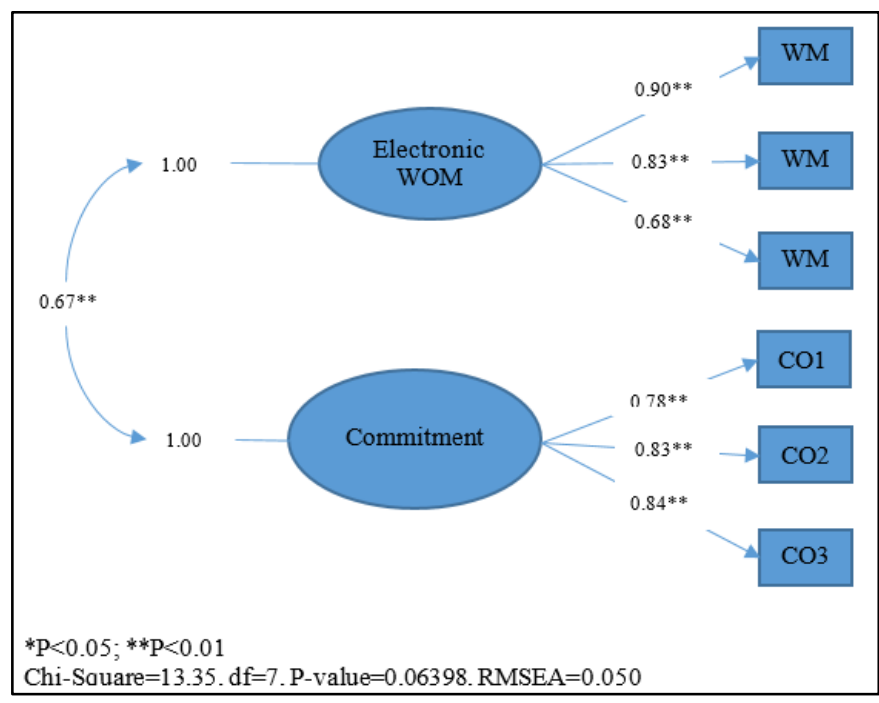

Figure 2: LISREL output for customer responses 
DOI: 10.14807/ijmp.v12i5.1425

\section{RESULTS}

Table 1 shows the indicators related to descriptive statistics for the sample, including the mean and standard deviation for the studied variables in this study.

Table 1: Descriptive indexes of variables

\begin{tabular}{lcc}
\hline Variable & Mean & SD \\
\hline Social medial marketing practices & 3.21 & 0.75 \\
Brand awareness & 3 & 1.02 \\
Brand image & 3.09 & 1.08 \\
Electronic word-of-mouth & 2.87 & 1.05 \\
Commitment & 2.91 & 0.97 \\
\hline
\end{tabular}

\subsection{Coefficient of Correlation between Variables}

Pearson correlation coefficient was used to identify the relationship between the variables in the model. Findings obtained from the coefficient of correlation between the variables are listed in Table 2. Findings show that the coefficient of correlation between social media marketing practices and brand awareness $(r=0.45)$, brand image $(r=0.40)$, electronic word of mouth $(\mathrm{r}=0.42)$ and commitment $(\mathrm{r} 0.44)=)$ is positive and significant. The coefficient of correlation between brand awareness and brand image $(r=0.51)$, electronic word of mouth $(r=0.45)$, and commitment $(r=0.47)$ is positive and significant. The coefficient of correlation between brand image and electronic word of mouth advertising $(r=0.46)$ and commitment $(r$ $=0.42$ ) is positive and significant. The coefficient of correlation between the electronic word of mouth and commitment $(r=0.57)$ is positive and significant.

Table 2: Matrix of correlation between constructs

\begin{tabular}{lccccc}
\hline Variable & 1 & 2 & 3 & 4 & 5 \\
\hline 1. social media marketing practices & 1 & & & & \\
2. brand awareness & $0.45^{* *}$ & 1 & & & \\
3. brand image & $0.40^{* *}$ & $0.51^{* *}$ & 1 & & \\
4. electronic word of mouth & $0.42^{* *}$ & $0.45^{* *}$ & $0.46^{* *}$ & 1 & \\
5. commitment & $0.44^{* *}$ & $0.47^{* *}$ & $0.42^{* *}$ & $0.57^{* *}$ & 1 \\
\hline \multicolumn{5}{c}{$\mathrm{p}<0.05^{* *} \mathrm{p}<0.01$}
\end{tabular}

\subsection{Structural Model Testing}

Figure 5 shows the tested model with standardized values on each of the paths. Findings show that all coefficients are positive and significant. Table 3 lists the coefficients of direct and indirect effects and the variance explained.

As shown in Table 3, the effect of social media marketing practices is positive and significant on brand image and brand awareness. The effect of brand image and brand awareness is positive and significant on electronic word of mouth and commitment. The 
INDEPENDENT JOURNAL OF MANAGEMENT \& PRODUCTION (IJM\&P)

http://www.ijmp.jor.br

v. 12, n. 5, July-August 2021

ISSN: 2236-269X

DOI: 10.14807/ijmp.v12i5.1425

indirect effect of social media marketing practices is positive and significant on electronic word of mouth and commitment through brand image and brand awareness.

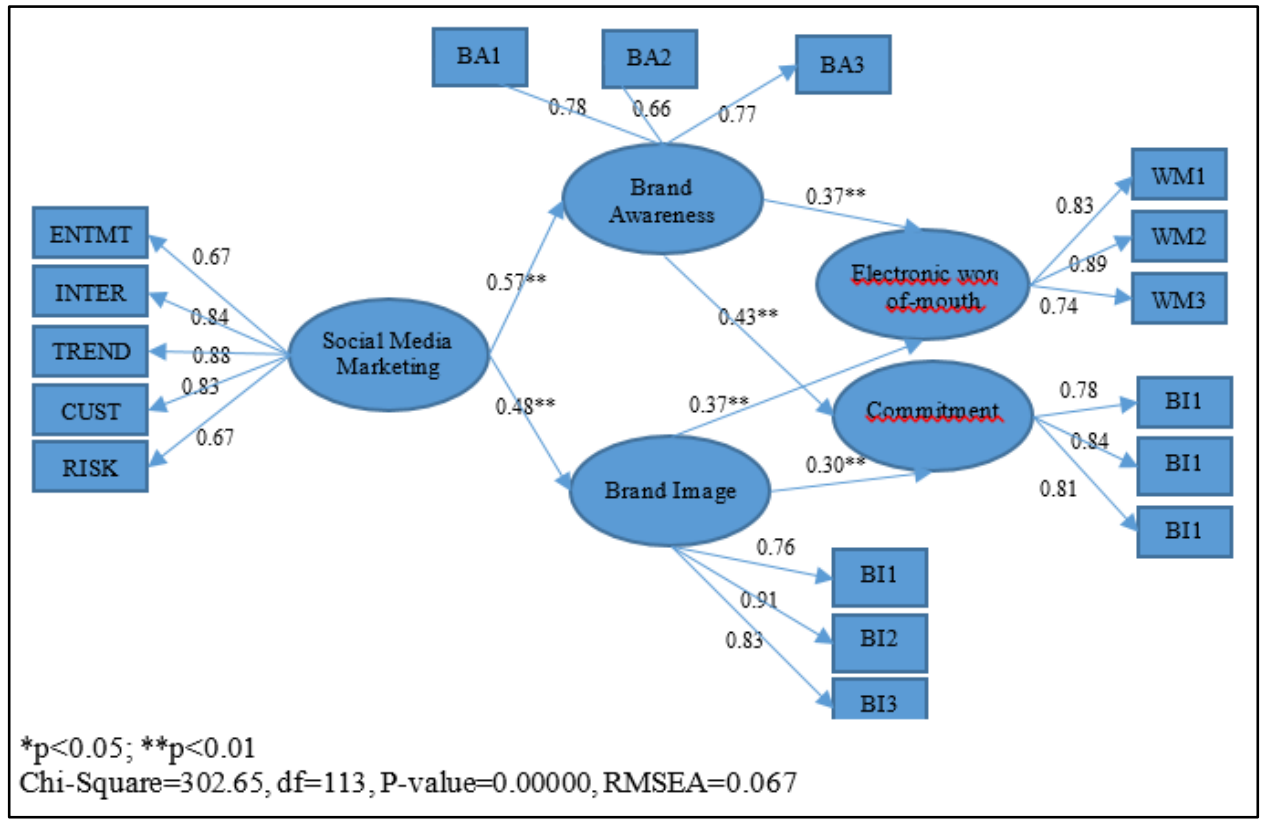

Figure 3: Standardized coefficients of the tested model

Table 3: coefficients of direct and indirect effects and variance explained

\begin{tabular}{|c|c|c|c|}
\hline Path & Direct effect & Indirect effect & Variance explained \\
\hline On commitment vie: & & & \multirow{4}{*}{$35 \%$} \\
\hline Brand awareness & $0.43 * *$ & - & \\
\hline Brand image & $0.30 * *$ & - & \\
\hline Social media marketing practices & - & $0.39 * *(8.36)$ & \\
\hline On electronic word of mouth vie: & & & \multirow{4}{*}{$34 \%$} \\
\hline Brand awareness & $0.37 * *$ & - & \\
\hline Brand image & $0.37 * *$ & - & \\
\hline Social media marketing practices & - & $0.39 * *(8.51)$ & \\
\hline $\begin{array}{l}\text { On brand image vie: } \\
\text { Social media marketing practices }\end{array}$ & $0.48 * *$ & - & $23 \%$ \\
\hline $\begin{array}{l}\text { On brand awareness vie: } \\
\text { Social media marketing practices }\end{array}$ & $0.57 * *$ & - & $32 \%$ \\
\hline
\end{tabular}

As shown in Table 3, 35\% of variance in commitment, 34\% of variance in electronic word of mouth, $23 \%$ of variance in brand image, and 32\% of variance in brand awareness are explained by the variables in the present model.

The fit indices obtained for the model tested in Table 4 show that RMSEA=0.067 in the estimated model is acceptable and other indexes including $\mathrm{CFI}=0.97$, GFI $=0.94, \mathrm{NFI}=0.95$, and AGFI $=0.91$ are good; these goodness of fit indices show that the data obtained in this study are well fitted to factor structure of this model. 
DOI: 10.14807/ijmp.v12i5.1425

Table 4: fit indexes of the fitted model

\begin{tabular}{ccc}
\hline Index & Estimate & Criterion \\
\hline$\chi^{2} / \mathrm{df}$ & 2.68 & $\chi^{2} / \mathrm{df}<3$ \\
RMSEA & 0.067 & $\mathrm{RMSEA}<0.08$ \\
GFI & 0.94 & $\mathrm{GFI}>0.9$ \\
AGFI & 0.91 & $\mathrm{AGFI}>0.9$ \\
CFI & 0.97 & $\mathrm{CFI}>0.9$ \\
NFI & 0.95 & $\mathrm{NFI}>0.9$ \\
\hline
\end{tabular}

\section{DISCUSSION}

The results showed that the effect of social media marketing practices is positive and significant on brand awareness. Therefore, social media marketing practices increase brand awareness. This finding is consistent with Seo and Park (2018) and Godey et al. (2016). Communication between people, groups, products, and companies through social media and provision of information leads to confidence, attachment, brand enthusiasm and thus increases brand awareness.

Therefore, brand awareness will increase if the store uses social media to share information about services and products, can exchange and transmit information through social media about services and products, provide customers with new and up-to-date information about services and products through social media, use social media to introduce services and products and enable customers to search for information through social media.

The results showed that the effect of social media marketing practices is positive and significant on brand image. Therefore, social media marketing practices increase brand image. This finding is consistent with Seo and Park (2018) and Godey et al. (2016). Brand image will be improved if using social media is entertaining for customers, social media content seems interesting to customers, social media enables customers to share information, chat, or exchange ideas with others through social media, it is easy to express opinions on social media, social media content has the latest information, social media recommend custom information search and provide custom services, customers like to share information about the brand, products, and services of the store to their friends through social media and like to share information content of social media in their weblogs or channels.

The results showed that the effect of brand awareness is positive and significant on electronic word of mouth. Therefore, brand awareness leads to an increase in electronic wordof-mouth. This finding is consistent with Seo and Park (2018) and Godey et al. (2016). Electronic word-of-mouth will increase if customers always are aware of the store, features of 
DOI: 10.14807/ijmp.v12i5.1425

the store are quickly evoked in their minds and they can quickly remember the symbols or logos of the store.

The results showed that the effect of brand image is positive and significant on electronic word of mouth. Therefore, brand image leads to an increase in electronic word-ofmouth. This finding is consistent with Seo and Park (2018) and Godey et al. (2016). Customers use the brand image of a product/service to have a general perception of a particular product/service.

A product with a better brand image makes customers or consumers perceive the product as better and more valuable, and thus advertise about it. Therefore, if the brand image of customers from the store is its use of quality and up-to-date products and services, a high reputation and credibility due to the quality of its services, it will lead to an increase in electronic word-of-mouth.

The results showed that the effect of brand awareness is positive and significant on commitment. Therefore, brand awareness leads to increased commitment. This finding is consistent with Seo and Park (2018) and Godey et al. (2016). Customer commitment to the store will increase if customers quickly remember the store they use, identify it among other competing stores, have a lot of information about the service and quality of the store, and recognize the symbol or logo of the store.

The results showed that the effect of brand image is positive and significant on commitment. Therefore, brand image leads to increased commitment. This finding is consistent with Seo and Park (2018) and Godey et al. (2016). If the customers consider the store as a representative of their industry, have significant (effective) memories about the store and customer orientation is one of the initial goals of the store, customer commitment will increase. Thus, customers will be proud to use the store's products/services, use the store's products/services in the long run, and feel committed to using the store's products/services.

\section{CONCLUSION}

Social media use mobile and web-based technologies to create highly interactive systems through which people and communities can share, discuss, and modify user-generated content. As a result, social media plays an important role in marketing activities. Therefore, the present study examined the relationship between social media marketing practices and customer response with consideration of the mediating role of brand equity dimensions. This study helps managers and executives of companies that use social media to identify the 
DOI: 10.14807/ijmp.v12i5.1425

effective factors on customer response and use it to influence consumer behavior to maintain customer loyalty.

\section{1. $\quad$ Answering the hypotheses}

- H1: There is a significant relationship between social medial marketing practices and brand awareness.

The results showed that the effect of social media marketing practices is positive and significant on brand awareness. Therefore, Digikala store managers are encouraged to use social media to share information about services and products. They are encouraged to develop the ability to exchange and transmit information about services and products through social media and provide new and up-to-date information about their services and products through social media to customers. They are encouraged to use social media to introduce their services and products and enable customers to search for information through social media.

- H2: There is a significant relationship between social medial marketing practices and brand image.

The results showed that the effect of social media marketing practices is positive and significant on brand image. Therefore, Digikala store managers are advised to make the use of social media entertaining for customers, provide interesting social media content for customers, Social media should enable customers to share information, make conversation or exchange with others possible through social media, and make it easy to express ideas through social media. Social media content should have the latest information. Social media should offer customized data searches and provide customized services. Customers should like to share information about the store's brand, products, and services to friends through social media, and like to share the store's social media information content on their blogs or channels.

- H3: There is a significant relationship between brand awareness and electronic wordof-mouth.

The results showed that the effect of brand awareness is positive and significant on electronic word of mouth. Therefore, Digikala store managers are advised to focus on brand management and apply awareness and communication strategies between products and consumers during brand competition in the market. Because brand awareness is the ability to recognize and remind potential buyers about a brand as a member of a particular category of products/services. Thus, marketers should focus on brand management and apply awareness 
DOI: 10.14807/ijmp.v12i5.1425

and communication strategies between products and consumers during brand competition in the market.

- H4: There is a significant relationship between brand image and electronic word-ofmouth.

The results showed that the effect of brand image is positive and significant on electronic word of mouth. Therefore, the managers of Digikala store are recommended to increase electronic word of mouth by using advanced and up-to-date technologies, high reputation, and credibility due to the quality of services. Creating a mental image is an essential tool for attracting and retaining customers. The brand image leads to perceived quality, positive attitude, and an overall positive impact, thus increasing brand equity. Brand image is associated with the links created in the consumer memory. Since the brand image is the basis of differentiating products, generalizing brand name, providing a reason to buy, and creating positive feelings about the brand, it helps the process of generalizing the consumer purchase.

- H5: There is a significant relationship between brand awareness and commitment.

The results showed that the effect of brand awareness is positive and significant on commitment. Therefore, the managers of Digikala store are recommended to provide conditions by providing quality products/services that customers can quickly remember the store, recognize it among other competing stores, have a lot of information about the service and quality of the store, and recognize the symbol or logo of the store and thereby increase customer commitment.

- H6: There is a significant relationship between brand image and commitment.

The results showed that the effect of brand image is positive and significant on commitment. Therefore, Digikala store managers are encouraged to provide quality products/services by providing conditions for customers so that they consider the store as a representative of its industry, have significant (effective) memories of the store; the managers should consider customer-orientation as the initial goals of the store to increase customer commitment.

\section{2. $\quad$ Remarks for Future Studies}

As noted, the present study was conducted among customers of Digikala store. It is suggested that the model presented in this study be implemented in other stores and the results be compared with the results of this study. 
DOI: 10.14807/ijmp.v12i5.1425

The approach of the present study is quantitative. It is suggested that future studies use a qualitative approach or mixed qualitative and quantitative approach (mixed method) to develop a model for identifying the effective factors on electronic word-of-mouth and customer commitment.

It is suggested that other studies examine the role of other effective factors on electronic word of mouth and customer commitment such as perceived quality, brand association, brand attachment, etc.

\section{REFERENCES}

Aaker, D. A. (1996). Measuring brand equity across products and markets. California Management Review, 38(3), 102-120

Ahmed, Y. A., Ahmad, M. N., Ahmad, N., \& Zakaria, N. H. (2019). Social media for knowledge-sharing: A systematic literature review. Telematics and informatics, 37(1), $72-$ 112.

Ansary, A., \& Hashim, N. M. H. N. (2018). Brand image and equity: The mediating role of brand equity drivers and moderating effects of product type and word of mouth. Review of Managerial Science, 12(4), 969-1002.

Chang, H. H., \& Liu, Y. M. (2009). The impact of brand equity on brand preference and purchase intentions in the service industries. The Service Industries Journal, 29(12), 16871706.

Chen, J., \& Shen, X. L. (2015). Consumers' decisions in social commerce context: An empirical investigation. Decision Support Systems, 79(1), 55-64.

Clark, M., Black, H. G., \& Judson, K. (2017). Brand community integration and satisfaction with social media sites: a comparative study. Journal of Research in Interactive Marketing., 11(1), 39-55

Gholami, M. H., Asli, M. N., Nazari-Shirkouhi, S., \& Noruzy, A. (2013). Investigating the influence of knowledge management practices on organizational performance: an empirical study. Acta Polytechnica Hungarica, 10(2), 205-216.

Godey, B., Manthiou, A., Pederzoli, D., Rokka, J., Aiello, G., Donvito, R., \& Singh, R. (2016). Social media marketing efforts of luxury brands: Influence on brand equity and consumer behavior. Journal of business research, 69(12), 5833-5841.

Heggestuen, J., \& Danova, T. (2013). Brand presence: How to choose where to be on social media. Business Insider.

Hsu, L., \& Lawrence, B. (2016). The role of social media and brand equity during a product recall crisis: A shareholder value perspective. International journal of research in Marketing, 33(1), 59-77.

Hudson, S., Roth, M. S., Madden, T. J., \& Hudson, R. (2015). The effects of social media on emotions, brand relationship quality, and word of mouth: An empirical study of music festival attendees. Tourism management, 47(1), 68-76. 
Kim, A. J., \& Ko, E. (2012). Do social media marketing activities enhance customer equity? An empirical study of luxury fashion brand. Journal of Business research, 65(10), 14801486.

Kim, H. W., Gupta, S., \& Koh, J. (2011). Investigating the intention to purchase digital items in social networking communities: A customer value perspective. Information \& Management, 48(6), 228-234.

Kim, J. H., \& Hyun, Y. J. (2011). A model to investigate the influence of marketing-mix efforts and corporate image on brand equity in the IT software sector. Industrial marketing management, 40(3), 424-438.

Kotler, P., Keller, K. L., Ancarani, F., \& Costabile, M. (2014). Marketing management, 14/e. Pearson.

Kumar, A., Bezawada, R., Rishika, R., Janakiraman, R., \& Kannan, P. K. (2016). From social to sale: The effects of firm-generated content in social media on customer behavior. Journal of Marketing, 80(1), 7-25.

Litvin, S. W., Goldsmith, R. E., \& Pan, B. (2008). Electronic word-of-mouth in hospitality and tourism management. Tourism management, 29(3), 458-468.

Moise, M. S., Gil-Saura, I., Šerić, M., \& Molina, M. E. R. (2019). Influence of environmental practices on brand equity, satisfaction and word of mouth. Journal of Brand Management, 26(6), 646-657.

Moliner-Velázquez, B., Fuentes-Blasco, M., \& Gil-Saura, I. (2019). Effects of value and innovation on brand equity in retailing. Journal of Brand Management, 26(6), 658-674.

Noruzy, A., Dalfard, V. M., Azhdari, B., Nazari-Shirkouhi, S., \& Rezazadeh, A. (2013). Relations between transformational leadership, organizational learning, knowledge management, organizational innovation, and organizational performance: an empirical investigation of manufacturing firms. The International Journal of Advanced Manufacturing Technology, 64(5-8), 1073-1085.

Nguyen, B., Yu, X., Melewar, T. C., \& Chen, J. (2015). Brand innovation and social media: Knowledge acquisition from social media, market orientation, and the moderating role of social media strategic capability. Industrial Marketing Management, 51(1), 11-25.

Olson, D. L., Cao, Q., Gu, C., \& Lee, D. (2009). Comparison of customer response models. Service Business, 3(2), 117-130.

Ramanathan, U., Subramanian, N., \& Parrot, G. (2017). Role of social media in retail network operations and marketing to enhance customer satisfaction. International Journal of Operations and Production Management, 37(1), 105-123.

Rapp, A., Beitelspacher, L. S., Grewal, D., \& Hughes, D. E. (2013). Understanding social media effects across seller, retailer, and consumer interactions. Journal of the Academy of Marketing Science, 41(5), 547-566.

Seo, E. J., \& Park, J. W. (2018). A study on the effects of social media marketing activities on brand equity and customer response in the airline industry. Journal of Air Transport Management, 66(1), 36-41. 